\title{
THE EFFECT OF VASECTOMY ON THE ACTIVITY OF PROSTATIC RNA POLYMERASE IN RATS
}

\author{
C. G. PIERREPOINT AND P. DAVIES \\ Tenovus Institute for Cancer Research, Heath Park, Cardiff CF 4 XX
}

(Received 17th April 1973)

Prostatic hypertrophy is androgen-dependent although the measurement of circulating levels of plasma steroids has not provided the expected information explaining the onset of this condition. Should another route be available to allow for testicular influence on the prostate, then other avenues become available to explain the age-related changes that occur in this organ.

A possible direct anatomical link is provided between the testes and the prostate by the excurrent duct system (i.e. seminiferous tubules, rete testis, vasa efferentia, epididymal ducts and the vasa deferentia). Such a connection might provide the means by which androgenic hormones could be transported from their site of origin to the target organs without having to enter the general circulation. Skinner \& Rowson $(1967,1968)$ showed that severing the vasa deferentia caused a reduction in weight and fructose and citric acid content of the ampullae. These were restored to normal following daily infusion of testosterone along the vasa.

To test the hypothesis that a direct hormonal influence could similarly be imposed on the prostate, four groups of six male Sprague-Dawley rats (Charles Rivers, U.K.) were taken. All the animals in any one group were of the same age to the day. Three animals in each group were vasectomized (double ligation of the vasa with removal of a $1-\mathrm{cm}$ section) and three (controls) were subjected to sham-operation. Anaesthesia was induced by intraperitoneal injection of $0.3 \mathrm{ml}$ of a suspension of Themalon (diethyl thiambutene hydrochloride, Burroughs Wellcome \& Co.) in Nembutal (pentobarbitone sodium, Abbot Labs. $60 \mathrm{mg} / \mathrm{ml})(50 \mathrm{mg} / 2 \mathrm{ml})$. The rats in Groups 1 and 2 were killed 5 to 6 weeks and 10 weeks after operation, respectively, whilst those in Group 3 were given intramuscular PMSG (Gestyl, Organon, U.K., 50 i.u./day) for 5 days and those in Group 4 were given intramuscular HCG (Pregnyl Organon, U.K., 10 i.u./day) for 5 days. The rats in the latter two groups were killed the day after completing the hormone therapy.

The PMSG and HCG were administered in an attempt to compare the stimulatory effect of the former on the seminiferous tubules and in particular their steroidogenic capacity (Christensen \& Mason, 1965) with that of the latter on the interstitial cells.

The ventral lobes of the prostate were immediately excised, weighed, chilled in ice and washed with $2 \mathrm{ml} 0.25 \mathrm{M}$-sucrose containing $1.0 \mathrm{~mm}^{-\mathrm{MgCl}_{2}}$. All procedures were carried out at 0 to $3^{\circ} \mathrm{C}$. Each gland was minced with scissors 
and homogenized in $2 \mathrm{ml} 0.25 \mathrm{M}$-sucrose- $1.0 \mathrm{~mm}^{-\mathrm{MgCl}_{2}}$, using a PotterElvehjem homogenizer with a motor-driven Teflon pestle having a clearance of 0.15 to $0.23 \mathrm{~mm}$. Homogenates were filtered through sterile gauze and the filtrate was centrifuged at $800 \mathrm{~g}$ for $15 \mathrm{~min}$. The pellets were washed by resuspension in $0.25 \mathrm{M}$-sucrose- $\mathrm{I} .0 \mathrm{~mm}-\mathrm{MgCl}_{2}$ and resedimented at $800 \mathrm{~g}$ for $15 \mathrm{~min}$. Pellets were then resuspended by gentle hand homogenization in $2 \cdot 2$ M-sucrose- $1.0 \mathrm{~mm}-\mathrm{MgCl}_{2}$ and centrifuged at $50,000 \mathrm{~g}$ for $1 \mathrm{hr}$ in the SW50 $3 \times 5 \mathrm{ml}$ swinging-bucket rotor $\left(r_{\mathrm{av} .}=7.3 \mathrm{~cm}\right)$ at $3^{\circ} \mathrm{G}$ in the Beckman L65B preparative ultracentrifuge. The nuclear preparations, containing 60 to $70 \%$ of tissue nuclei in a purified form, were each resuspended in $1.0 \mathrm{ml} 0.25$ M-sucrose-1.0 mM- $\mathrm{MgCl}_{2}$.

The activities of DNA-dependent RNA polymerase (nucleoside triphosphateRNA nucleotidyltransferase, EC 2.7.7.6) were estimated in $500 \mu \mathrm{l}$ of a medium containing $2.5 \mu \mathrm{mol} \mathrm{MgCl}, 15 \mu \mathrm{mol} \mathrm{KCl,} 200 \mathrm{nmol}$ dithiothreitol, $300 \mathrm{nmol}$ $\mathrm{NaF}, 60 \mu \mathrm{mol}$ tris-HCl buffer, $\mathrm{pH} 8 \cdot 1,300 \mathrm{nmol}$ each of ATP, GTP and CTP, $20 \mathrm{nmol}$ carrier UTP and $125 \mathrm{pmol}\left[\mathrm{U}-{ }^{14} \mathrm{C}\right] \mathrm{UTP}$ (specific radioactivity 514 mGi/mmol; The Radiochemical Centre, Amersham, Bucks., U.K.). Enzyme reactions $\left(15 \mathrm{~min}\right.$ at $37^{\circ} \mathrm{C}$ ) were initiated by the addition of $250 \mu \mathrm{l}$ nuclear suspension ( 15 to $50 \mu \mathrm{g} \mathrm{DNA}$ ) and terminated by the addition of $2 \mathrm{ml}$ of $10 \%$ $(\mathrm{w} / \mathrm{v})$ trichloroacetic acid containing $\mathrm{I} \cdot 0 \mathrm{~mm}-\mathrm{Na}_{4} \mathrm{P}_{2} \mathrm{O}_{7}$. Washing and preparation of precipitates for assessment of the radioactivity in the acid-insoluble material was carried out as previously described (Davies, Fahmy, Pierrepoint \& Griffiths, 1972). The DNA content of filtered whole homogenates and nuclear suspensions was estimated by the diphenylamine procedure of Burton (1956) as modified by Giles \& Myers (1965), using calf thymus DNA as standard. The RNA content was estimated by the orcinol method of Mejbaum (1939), using yeast RNA as standard. Incorporation of $\left[{ }^{14} \mathrm{C}\right] \mathrm{UMP}$ into acid-insoluble material was calculated as ct/min/100 $\mu \mathrm{g}$ DNA, after correction for zero-time controls. The results are shown in Text-fig. 1.

To examine the prostatic uptake of an androgen infused along the vasa deferentia, a male Sprague-Dawley rat was anaesthetized and the vasa were exposed lateral to the genital papilla and severed. Portex intravenous catheters (o.d. $0.63 \mathrm{~mm}$ ) were inserted into the lumen of each and connected to separate 1 -ml syringes containing $50 \mu \mathrm{Ci}\left[7 \alpha_{-}{ }^{3} \mathrm{H}\right]$ testosterone $(5 \mathrm{Ci} / \mathrm{mmol}$, Radiochemical Centre, Amersham) in $1.5 \%$ ethanol in saline. After the 24-min infusion period, the prostatic lobes and other organs were removed to assess uptake of radioactivity. The results are shown in Text-fig. 2 .

The levels of activity of RNA polymerase in the ventral lobes of the prostate of vasoligated and control animals (Text-fig. 1) showed that a significant reduction had been achieved following ligation and the response of the enzyme to trophic hormone administration had been suppressed. The enzyme system responded to both PMSG and HCG in ligated and control animals although the significance of the difference between the two groups of animals was greater with the more enhanced activity.

The uptake of $\left[7 \alpha-{ }^{3} \mathrm{H}\right]$ testosterone by androgen- and non-androgen-dependent target organs (Text-fig. 2) shows that the highest concentrations were achieved in the various prostatic lobes, and in the urine. The latter may be 


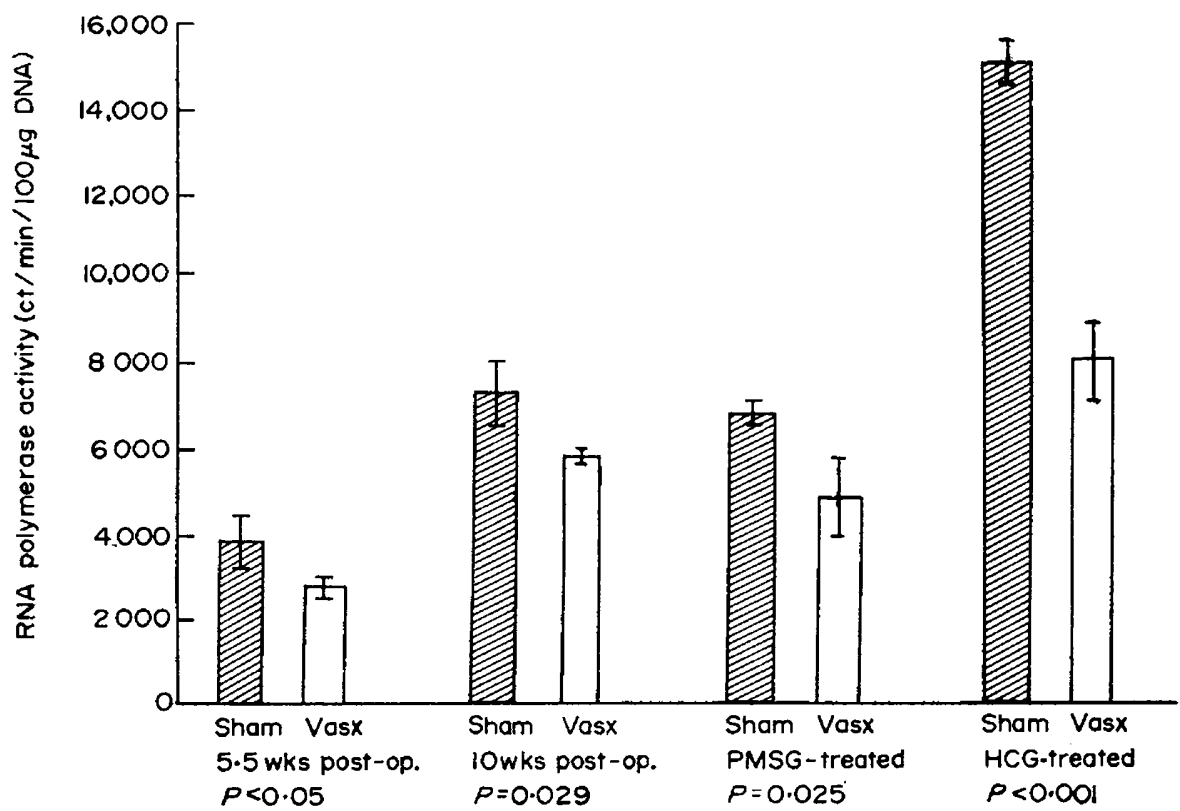

Untreated onimals

TExT-FIG. 1. The effect of vasoligation on RNA polymerase activity in the rat ventral prostate with or without the influence of gonadotrophic hormones.

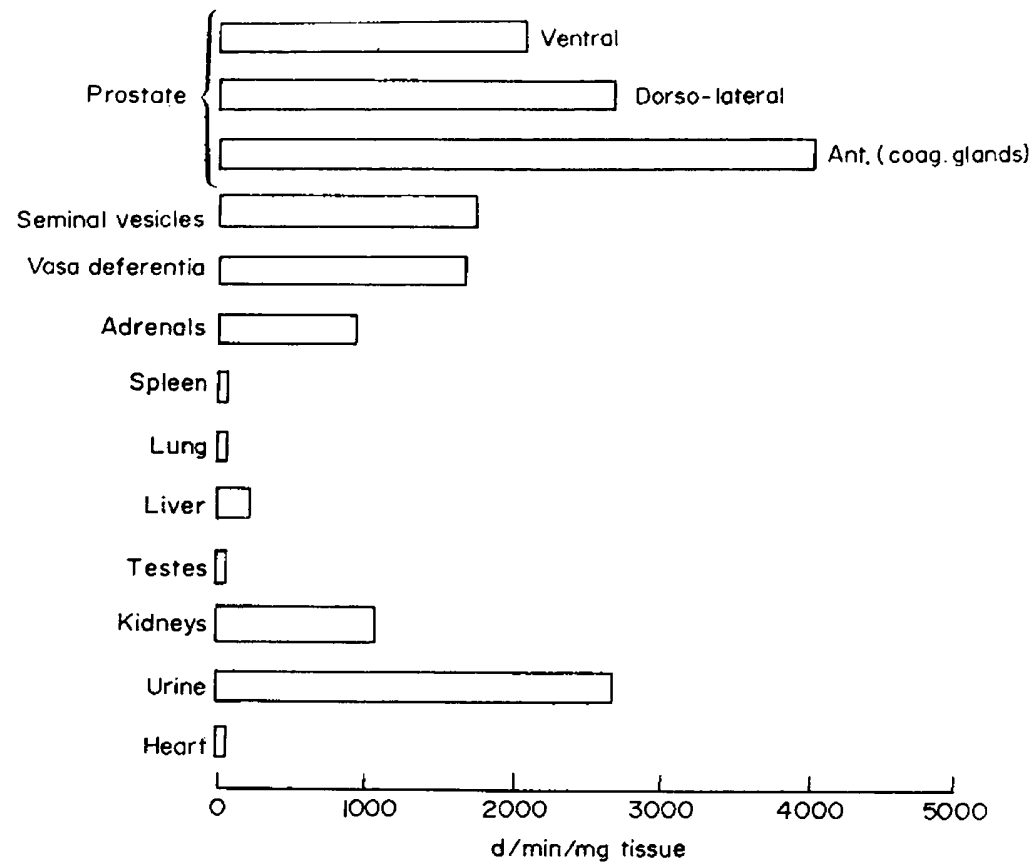

TEXT-FIG. 2. The uptake of radioactivity (d./min $/ \mathrm{mg}$ wet weight) in various organs of the rat after the bilateral infusion in vivo of $\left[7 \alpha^{3} \mathrm{H}\right]$ testosterone along the vasa deferentia. 
explained by the reflux of radioactive material into the bladder through the urethra.

These results indicate that vasoligation will reduce the level of activity of the ventral prostate RNA polymerase and that labelled testosterone infused along the vasa will be preferentially taken up by the prostate and seminal vesicles. The implication is that there is normally a passage of androgenic material from the testes along the vas deferentia that can enter prostatic tissue and influence its androgen-dependent enzymes.

The authors wish to thank Miss Gail Harvey and Miss Barbara John for their expert technical assistance and Mr D. Mulcuck and Mr A. Pike for skilled aid in the theatre. Financial assistance was generously provided by the Tenovus Organization.

\section{REFERENCES}

Burton, K. (1956) A study of the conditions and mechanism of the diphenylamine reaction for the colorimetric estimation of deoxyribonucleic acids. Biochem. 7. 62, 315.

Christensen, A. K. \& Mason, N. R. (1965) Comparative ability of seminiferous tubules and interstitial tissue of rat testes to synthesize androgens from progesterone $-4-{ }^{14} \mathrm{C}$ in vitro. Endocrinology, $76,646$.

Davies, P., Fahmy, A. R., Pierrepoint, C. G. \& Griffiths, K. (1972) Hormonal effects in vitro on ribonucleic acid polymerase. Biochem. 7. 129, 1167.

GiLes, K. W. \& MYers, A. (1965) An improved method for the estimation of deoxyribonucleic acid. Nature, Lond. 256, 93.

Mejbaum, W. (1939) Uber die Bestimmung kleiner Pentose Mengen insbesondere in Derivaten der Adenylsaure. Hoppe-Seyler's Z. physiol. Chem. 258, 117.

Skinner, J. D. \& Rowson, L. E. A. (1967) Effects of unilateral cryptorchidism on sexual development in the pubescent male animal. $\mathcal{F}$. Reprod. Fert. 14, 349.

Skinner, J. D. \& Rowson, L. E. A. (1968) Some effects of unilateral cryptorchism and vasectomy on sexual development of the pubescent ram and bull. 7 . Endocr. 42, 311. 